\title{
Steam turbine efficiency assessment, first step towards sustainable electricity production
}

\author{
Sorina Anutoiu ${ }^{1}$, Ion Dosa ${ }^{1 *}$ and Dan Codrut Petrilean ${ }^{1}$ \\ ${ }^{1}$ University of Petrosani, Department of Mechanical, Industrial and Transport Engineering, 20 \\ Universitatii, Petrosani, Romania
}

\begin{abstract}
The main objective of actual energy policies around the world is the transition to renewable energy. EIA forecasts nearly $50 \%$ increase in world energy usage by 2050, which is hard to achieve using only renewable energy. For year 2019 the electricity production in EU relies mainly on conventional thermal (42.8\%) and nuclear energy sources $(26.7$ $\%)$. The accelerated transition to electrical cars puts more pressure on energy producers. As a result, in order to match the ever-growing demand of electrical energy, the conventional thermal energy generation will play a key role, among them coal-based production. In order to meet the environmental goals and for sustainable production of electrical power, energy assessment of power production of coal-based power plants must be performed. The purpose of this paper is to perform an energy assessment of the electrical power production, focusing on a key component of this, the steam turbine. The performance characteristics of the turbine in condensing operation were determined. A proper efficiency of the turbine will have a significant impact on sustainable production of electricity.
\end{abstract}

\section{Introduction}

In electricity production two of the Sustainable Development Goals must be taken into account: affordable and clean energy and responsible consumption and production.

At first glance, these goals are contradictory as the cost of renewable energy from solar and wind are higher than for "polluting energy" [1]. For example, in 2017 [1] an electricity supply company said that the current fixed rate for the company's clean energy was 14.8 cents per kilowatt hour, which compared to 8.2 cents a kilowatt hour for the electricity procured for customers by another one, through competitive bidding highlights the contradiction between clean energy and conventional energy.

Unfortunately, data regarding this issue is sometimes contradictory, as another source [2] highlights the dropping costs of renewable energy for a period of time between 20102019 as follows: $82 \%$ for solar photovoltaics, $47 \%$ for concentrating solar power, $39 \%$ for onshore wind and $29 \%$ for offshore wind. The fact that some countries set the price of energy from renewable sources contributes to increasing confusion about the true cost of renewable energy. For example, in Romania [3] the price set for 2019 was $4.7 €$ cent $/ \mathrm{kWh}$. Even if the price of energy from renewable sources is constantly decreasing, the choice

\footnotetext{
* Corresponding author: i_dosa@hotmail.com
} 
between renewable and conventional sources for electricity production must be made taking into account other criteria too.

An important criterion is the operational security is the short-term electricity security linked to events like short circuits or unplanned outages, mainly occurring in the infrastructure and source dimensions. The importance of this criteria is highlighted in several papers on grid security [4].

Despite the growth of renewable energy, coal still accounts for 24 percent of America's electricity [5]. Coal plants, nuclear and large natural gas facilities constitute "base-load" power that is critical for maintaining grid stability and reliability. Unlike intermittent wind and solar, coal plants and nuclear plants are "always on." A major advantage of coal plants over natural gas plants, is that they keep months of fuel on site, providing essential security and resiliency for the grid.

EIA (Energy Information Administration) [6] forecasts nearly 50\% increase in world energy usage by 2050 , which is hard to achieve using only renewable energy since the forecast for renewable energy points to $28.64 \%$ share of total energy consumption, while according to Centre for Climate and Energy Solutions [7] for year 2017 the share of renewable energy of total final energy consumption was $10.6 \%$.

For year 2019 [8] the electricity production in EU relies mainly on conventional thermal $(42.8 \%)$ and nuclear energy sources $(26.7 \%)$. The accelerated transition to electrical cars puts more pressure on energy producers [9], as the forecast for 2030 reveals that 1 in 5 cars will be electric.

As a result, in order to match the ever-growing demand of electrical energy, the conventional thermal energy generation will play a key role in securing grid stability and reliability, among them coal-based production. In order to meet the environmental goals and for sustainable production of electrical power, energy assessment of power production of coal-based power plants must be performed.

\section{Problem Presentation}

A steam turbine works by using a heat source, in this case coal, to heat water until it is converted into steam, at high temperatures. As that steam flows past a turbine spinning blades, it expands and cools, meanwhile the potential energy of the steam is turned into kinetic energy in the rotating turbine blades.

The highest inlet steam temperature currently applied to actual supercritical pressure and USC (Ultra Supercritical) steam turbines, is between $566^{\circ} \mathrm{C}$ and $620^{\circ} \mathrm{C}$ [10]. However, a next-generation A-USC (Advanced Ultra Supercritical) pressure steam turbine project is aiming at $700^{\circ} \mathrm{C}$ inlet temperature at a maximum inlet pressure of $31 \mathrm{MPa}$. In order to withstand high temperatures and pressures, steam turbines are specially built, complex equipment, with a long life-cycle.

As highlighted in literature [11] the average lifetime of a coal powered plant is 29 years although its design life is 40 to 50 years. About three-quarters of Australia's coal-fired power stations are operating beyond their original design life and some have had extensive refits as a result. It is not only in Australia that such power plants are operated, all around the world, many of them are still in use [12] after more than $30 \mathrm{yrs}$. of service.

Technology improvements driven by need of higher efficiency in order to meet Sustainable Development Goals, and reduce the cost of electricity production, led to a new generation of steam turbines. Assessment of energy performance of steam turbine, is the first step in decision making, and requires heat balance calculations. As in many countries, energy auditing in Romania must be carried out according to the published guide [13] by the regulatory authority ANRE which regulates and supervises these activities. In addition 
to the guide, heat balance calculations examples for various installations and equipment can be found in literature [14],[15].

\section{The balance outline for K-160-130-2PR-2 steam turbine}

K 160-130-2PR-2 steam turbine, presented in the schematic diagram of the $150 \mathrm{MW}$ unit (Fig. 1) is a condensing type turbine with uncontrolled bleed and was designed to operate at $12.8 \mathrm{MPa}$, and $540{ }^{\circ} \mathrm{C}$ with one steam reheat to a temperature of $540{ }^{\circ} \mathrm{C}$ at a pressure of $3.41 \mathrm{MPa}$. The exhaust pressure is $0.0038 \mathrm{MPa}$. At the listed steam parameters and with a cooling water temperature of $12{ }^{\circ} \mathrm{C}$, the calculated power of the turbine is $170 \mathrm{MW}$. It also can deliver up to $175 \mathrm{MW}\left(150 \mathrm{Gcal} \cdot \mathrm{h}^{-1}\right)$ of thermal energy from unregulated bleeder at $150 / 70{ }^{\circ} \mathrm{C}$ or $130 / 70{ }^{\circ} \mathrm{C}$ in the district heating network.

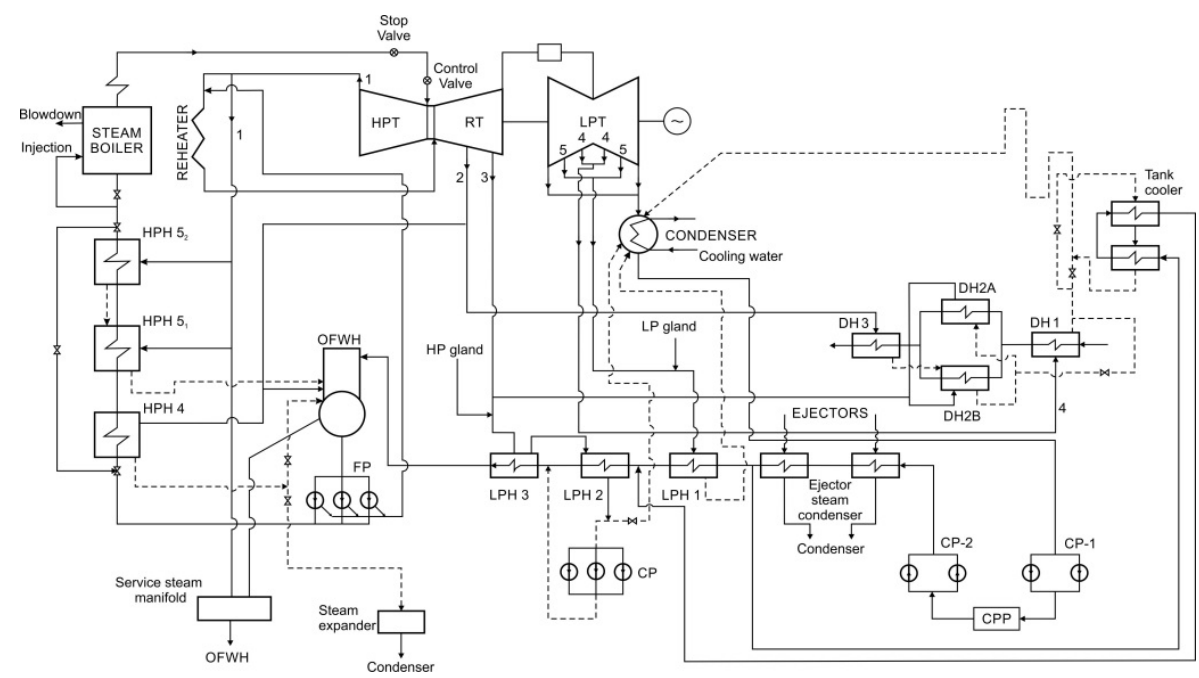

Fig. 1. Schematic diagram of $150 \mathrm{MW}$ unit [16].

Abbreviations: HPT - high pressure turbine; RT - reheat turbine; LPT - low pressure turbine; CP, CP-1, CP-2 - condensate pumps; LPH - low pressure feedwater heater; HPH high pressure feedwater heater; $\mathrm{FP}$ - feedwater pump; $\mathrm{DH}$ - district heating heat exchanger; $\mathrm{CPP}$ - condensate polishing plant.

The turbine has five bleeder connections for regenerative feed water heating to a maximum of $235.4{ }^{\circ} \mathrm{C}$. From the High-Pressure Turbine (HPT) steam is directed to reheater at a pressure of $3.12 \mathrm{MPa}$ and a temperature of $350.7{ }^{\circ} \mathrm{C}$ from which is returned to the Reheat Turbine (RT). The Low-Pressure Turbine (LPT) is of a double-flow design.

Steam for turbine is provided by a Babcock-Hitachi type steam generator, a natural circulation coal-fired boiler, with $540 \mathrm{t} \cdot \mathrm{h}^{-1}$ rated steam output. The steam output of generator is $540 \mathrm{t} \cdot \mathrm{h}^{-1}$, at a pressure of $13.85 \mathrm{MPa}$ and $541{ }^{0} \mathrm{C}$ for live steam and $471.4 \mathrm{t} \cdot \mathrm{h}^{-1}$ at $2.96 \mathrm{MPa}$ and $541{ }^{\circ} \mathrm{C}$ temperature for reheat steam. Feed water parameters at steam generator rated load are: pressure $18.8 \mathrm{MPa}$, temperature $235.4{ }^{\circ} \mathrm{C}$. In order to provide district heating, 3 heat exchangers where added, but since the demand is low only one heat exchanger having two bodies is in use. The steam required for water heating is drawn from bleeder 3 . 


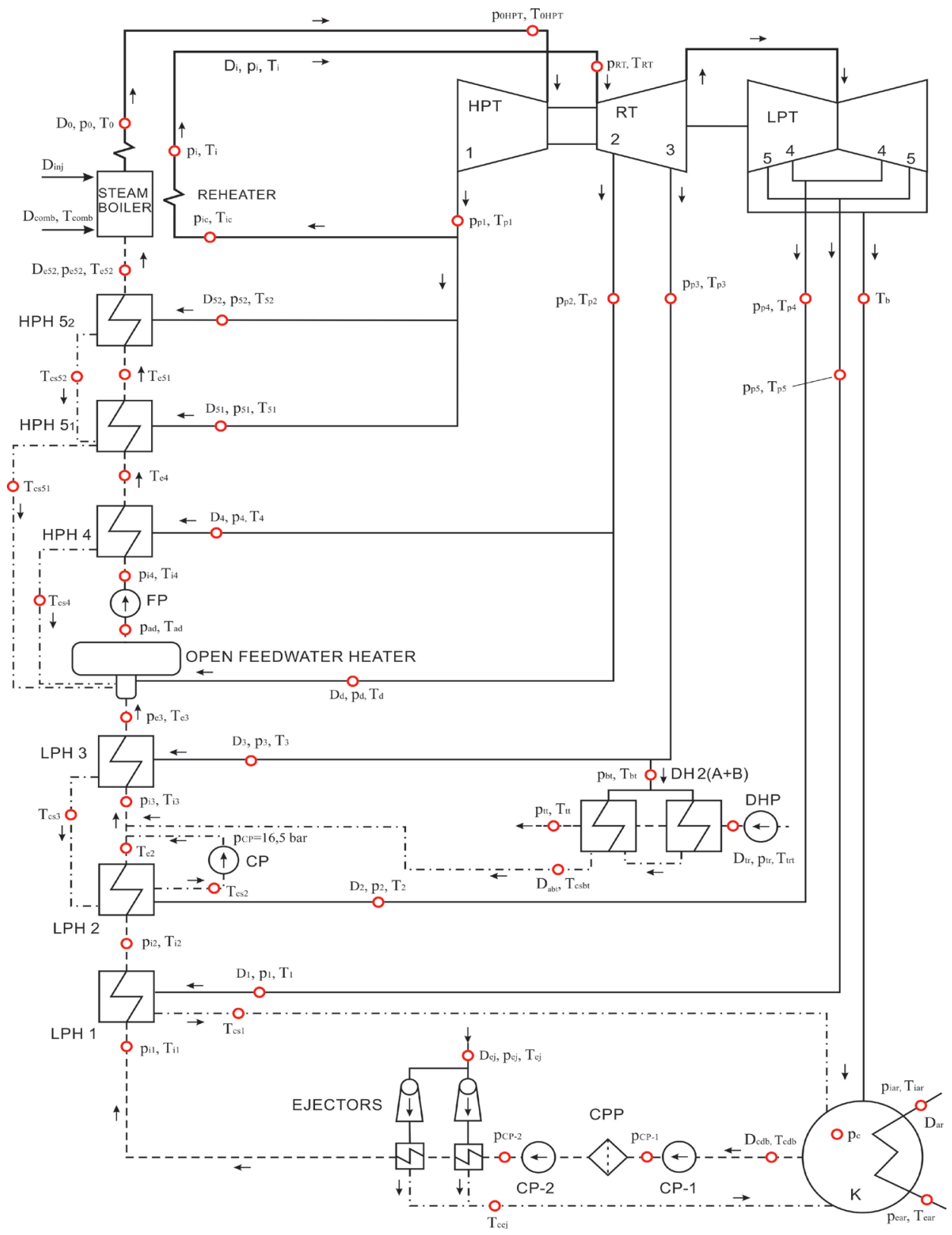

Fig. 2. Schematic diagram illustrating condensate, drain and feedwater flow.

Abbreviations: HPT - high pressure turbine; RT - reheat turbine; LPT - low pressure turbine; CP, CP-1, CP-2 - condensate pumps; LPH - low pressure feedwater heater; HPH high pressure feedwater heater; FP - feedwater pump; DH - district heating heat exchanger; DHP - district heating pump; CPP - condensate polishing plant; $\mathrm{K}$ - condenser.

Balance outline (Fig. 2.) is made up of: the main flow control valve of turbine on the steam side; the generator terminals for electricity output; outlet of HPH 52; inlet sections of cooling water used in condenser. 
Balance outline contains the steam turbine, the regenerative cycle, the regenerative feed water heaters; the condenser, feed water and condensate pumps.

\section{Measured data and results}

As regulations require, measurements for heat balance calculations must be carried out for at least 3 different loads, usually the minimum, average and rated load. The loads for performance tests were fixed to $115 \mathrm{MW}, 130 \mathrm{MW}$ and $150 \mathrm{MW}$ power output for condensation operation.

Data from the management and control system of the power plant were used, and in addition, measuring equipment was placed in different locations. Data acquisition points are symbolized with $\mathrm{O}$ in Fig. 2. Steam required by open feedwater heater was drawn off from bleeder no. 2. A rated flow of $14 \mathrm{t} \cdot \mathrm{h}^{-1}$ service steam is extracted from the pipeline at the HP outlet. The electrical generator rated power was $150 \mathrm{MW}$, while rated efficiency was $99.21 \%$ and mechanical efficiency was $98.7 \%$.

In order to complete water loss wakeup water was added into the condenser. The average temperature of the wakeup water was $32.9^{\circ} \mathrm{C}$ at 9 bar pressure.

The efficiency of LPH (Low Pressure Heaters) and HPH (High Pressure Heaters) was assumed $98 \%$, while de efficiency of boiler to steam turbine tubing was assumed $99 \%$.

During the measurements the average value of pressure at the discharge of condensate pump CP was 16.5 bar.

In order to increase the accuracy of flow rate computing for bleeders, flow rate of condensate at the outlet of steam condenser was measured with Flexim ultrasonic clamp-on flow meter.

Table. 1. Steam flow rate at low- and high-pressure heaters

\begin{tabular}{|l|r|r|r|}
\hline \multirow{2}{*}{ Nom. } & \multicolumn{3}{|c|}{ CONDENSATION } \\
\cline { 2 - 4 } & $\mathbf{1 1 5}$ MW & $\mathbf{1 3 0}$ MW & $\mathbf{1 5 0}$ MW \\
\hline Steam flow rate at HPH-5, $\mathrm{t} \cdot \mathrm{h}^{-1}$ & 1700 & 21,49 & 27.203 \\
\hline Steam flow rate at HPH-5 $1, \mathrm{t} \cdot \mathrm{h}^{-1}$ & 21.463 & 25.479 & 34.685 \\
\hline Steam flow rate at HPH-4, $\mathrm{t} \cdot \mathrm{h}^{-1}$ & 4.553 & 11.427 & 15.601 \\
\hline Steam flow rate at OFWH, $\mathrm{t} \cdot \mathrm{h}^{-1}$ & 2.935 & 3.021 & 0 \\
\hline Steam flow rate at LPH-3, $\mathrm{t} \cdot \mathrm{h}^{-1}$ & 38.739 & 42.943 & 49.547 \\
\hline Steam flow rate at LPH-2, $\mathrm{t} \cdot \mathrm{h}^{-1}$ & 4.462 & 6.791 & 10.341 \\
\hline Steam flow rate at LPH-1, $\mathrm{t} \cdot \mathrm{h}^{-1}$ & 3.024 & 3.47 & 6.043 \\
\hline Steam flow rate at ejectors, $\mathrm{t} \cdot \mathrm{h}^{-1}$ & 3.553 & 3.863 & 4.506 \\
\hline
\end{tabular}

Data resulting from calculations are presented in Table 2-6.

Table 2. Efficiency of HPT, RT and LPT at different loads

\begin{tabular}{|l|r|r|r|}
\hline Nom. & 115 MW & 130 MW & 150 MW \\
\hline HPT efficiency, \% & 62.61 & 63.63 & 65.97 \\
\hline RT efficiency, \% & 74.10 & 74.23 & 74.47 \\
\hline LPT efficiency, \% & 79.87 & 82.15 & 85.98 \\
\hline
\end{tabular}

Table 3. Actual hourly energy balance for $115 \mathrm{MW}$ load (condensation)

\begin{tabular}{|l|c|c|l|c|c|}
\hline INPUT & OUTPUT \\
\hline Nom. & MW & $\%$ & Nom. & MW & $\%$ \\
\hline ENERGY INPUT & & USEFUL OUTPUT & \\
\hline Energy of steam & 405.630 & 98.50 & Generator output power $P_{g}$ & 115.500 & 28.05 \\
\hline
\end{tabular}




\begin{tabular}{|c|c|c|c|c|c|}
\hline \multirow[t]{4}{*}{$\begin{array}{l}\text { (main and reheat) } \\
\mathrm{P}_{\mathrm{ta}}\end{array}$} & & & $\begin{array}{lll}\text { Energy } & \text { recovered } & \text { in } \\
\text { regenerative cycle } \mathrm{P}_{\text {cdr }} & \\
\end{array}$ & 101.231 & 24.58 \\
\hline & & & Energy of service steam $P_{\text {tech }}$ & 12.144 & 2.95 \\
\hline & & & TOTAL USEFUL & 228.875 & 55.58 \\
\hline & & & \multicolumn{3}{|l|}{ LOSSES } \\
\hline \multirow{4}{*}{$\begin{array}{l}\text { Energy recovered } \\
\text { in ejector steam } \\
\text { condenser } \mathrm{P}_{\mathrm{ej}}\end{array}$} & \multirow[t]{4}{*}{2.825} & \multirow[t]{4}{*}{0.69} & Mechanical loss $\Delta \mathrm{P}_{\mathrm{m}}$ & 1.950 & 0.47 \\
\hline & & & Generator loss $\Delta \mathrm{P}_{\mathrm{g}}$ & 1.360 & 0.33 \\
\hline & & & Heat rejected by condenser $\mathrm{P}_{\mathrm{cd}}$ & 185.380 & 45.02 \\
\hline & & & $\begin{array}{l}\text { Losses in steam boiler to turbine } \\
\text { tubing } P_{L}\end{array}$ & 1.642 & 0.40 \\
\hline \multirow{4}{*}{$\begin{array}{l}\text { Energy input of } \\
\text { feedwater and } \\
\text { condensate pumps } \\
\mathrm{P}_{\mathrm{p}}\end{array}$} & \multirow[t]{4}{*}{3.046} & \multirow[t]{4}{*}{0.74} & $\begin{array}{l}\text { Losses due to feedwater leakage } \\
\text { in regenerative heating system } \\
P_{\mathrm{pdr}}\end{array}$ & 1.355 & 0.33 \\
\hline & & & $\begin{array}{l}\text { Heat losses in regenerative } \\
\text { feedwater heating system } \mathrm{P}_{\mathrm{qr}}\end{array}$ & 1.461 & 0.35 \\
\hline & & & Unaccounted losses $\Delta \mathrm{P}_{\text {div }}$ & -10.217 & -2.48 \\
\hline & & & TOTAL ENERGY LOSS & 182.931 & 44.42 \\
\hline TOTAL INPUT & 411.806 & 100.00 & TOTAL OUTPUT & 411.806 & 100.00 \\
\hline
\end{tabular}

Table 4. Actual hourly energy balance for $130 \mathrm{MW}$ load (condensation)

\begin{tabular}{|c|c|c|c|c|c|}
\hline \multicolumn{3}{|l|}{ INPUT } & \multicolumn{3}{|l|}{ OUTPUT } \\
\hline Nom. & MW & $\%$ & Nom. & MW & $\%$ \\
\hline \multicolumn{3}{|l|}{ ENERGY INPUT } & \multicolumn{3}{|l|}{ USEFUL OUTPUT } \\
\hline \multirow{5}{*}{$\begin{array}{l}\text { Energy of steam } \\
\text { (main and reheat) } \\
\mathrm{P}_{\mathrm{ta}}\end{array}$} & \multirow[t]{5}{*}{471.680} & \multirow[t]{5}{*}{98.53} & Generator output power $\mathrm{Pg}_{\mathrm{g}}$ & 130.574 & 27.28 \\
\hline & & & $\begin{array}{l}\text { Energy recovered } \\
\text { regenerative cycle } P_{c d r}\end{array}$ & 121.729 & 25.43 \\
\hline & & & Energy of service steam $P_{\text {tech }}$ & 12.207 & 2.55 \\
\hline & & & TOTAL USEFUL & 264.510 & 55.26 \\
\hline & & & \multicolumn{3}{|l|}{ LOSSES } \\
\hline \multirow{4}{*}{$\begin{array}{l}\text { Energy recovered } \\
\text { in ejector steam } \\
\text { condenser } \mathrm{P}_{\mathrm{ej}}\end{array}$} & \multirow[t]{4}{*}{3.111} & \multirow[t]{4}{*}{0.65} & Mechanical loss $\Delta \mathrm{P}_{\mathrm{m}}$ & 1.950 & 0.41 \\
\hline & & & Generator loss $\Delta \mathrm{P}_{\mathrm{g}}$ & 1.361 & 0.28 \\
\hline & & & Heat rejected by condenser $P_{c d}$ & 216.482 & 45.22 \\
\hline & & & $\begin{array}{l}\text { Losses in steam boiler to turbine } \\
\text { tubing } P_{L}\end{array}$ & 1.505 & 0.31 \\
\hline \multirow{4}{*}{$\begin{array}{l}\text { Energy input of } \\
\text { feedwater and } \\
\text { condensate pumps } \\
\mathrm{P}_{\mathrm{p}}\end{array}$} & \multirow[t]{4}{*}{3.561} & \multirow[t]{4}{*}{0.75} & $\begin{array}{l}\text { Losses due to feedwater leakage } \\
\text { in regenerative heating system } \\
\mathrm{P}_{\mathrm{pdr}}\end{array}$ & 1.628 & 0.34 \\
\hline & & & $\begin{array}{l}\text { Heat losses in regenerative } \\
\text { feedwater heating system } \mathrm{P}_{\mathrm{qr}}\end{array}$ & 1.710 & 0.36 \\
\hline & & & Unaccounted losses $\Delta \mathrm{P}_{\text {div }}$ & -10.439 & -2.18 \\
\hline & & & TOTAL ENERGY LOSS & 214.197 & 44.74 \\
\hline TOTAL INPUT & 478.707 & 100.00 & TOTAL OUTPUT & 478.707 & $\begin{array}{r}100.0 \\
0\end{array}$ \\
\hline
\end{tabular}

Table 5. Actual hourly energy balance for $150 \mathrm{MW}$ load (condensation)

\begin{tabular}{|c|c|c|c|c|c|}
\hline \multicolumn{3}{|l|}{ INPUT } & \multicolumn{3}{|l|}{ OUTPUT } \\
\hline Nom. & MW & $\%$ & Nom. & MW & $\%$ \\
\hline \multicolumn{3}{|l|}{ ENERGY INPUT } & \multicolumn{3}{|l|}{ USEFUL OUTPUT } \\
\hline \multirow{5}{*}{$\begin{array}{l}\text { Energy of steam } \\
\text { (main and reheat) } \\
\mathrm{P}_{\mathrm{ta}}\end{array}$} & \multirow[t]{5}{*}{563.118} & \multirow[t]{5}{*}{98.55} & Generator output power $\mathrm{Pg}_{\mathrm{g}}$ & 149.802 & 26.22 \\
\hline & & & $\begin{array}{l}\text { Energy recovered } \\
\text { regenerative cycle } P_{c d r}\end{array}$ & 150.797 & 26.39 \\
\hline & & & Energy of service steam $P_{\text {tech }}$ & 12.280 & 2.15 \\
\hline & & & TOTAL USEFUL & 312.879 & 54.76 \\
\hline & & & LOSSES & & \\
\hline
\end{tabular}




\begin{tabular}{|c|c|c|c|c|c|}
\hline \multirow{4}{*}{$\begin{array}{l}\text { Energy recovered } \\
\text { in ejector steam } \\
\text { condenser } \mathrm{P}_{\mathrm{ej}}\end{array}$} & \multirow[t]{4}{*}{3.572} & \multirow[t]{4}{*}{0.63} & Mechanical loss $\Delta \mathrm{P}_{\mathrm{m}}$ & 1.950 & 0.34 \\
\hline & & & Generator loss $\Delta \mathrm{P}_{\mathrm{g}}$ & 1.335 & 0.23 \\
\hline & & & Heat rejected by condenser $\mathrm{P}_{\mathrm{cd}}$ & 262.759 & 45.98 \\
\hline & & & $\begin{array}{l}\text { Losses in steam boiler to turbine } \\
\text { tubing } P_{L}\end{array}$ & 0.595 & 0.10 \\
\hline \multirow{4}{*}{$\begin{array}{l}\text { Energy input of } \\
\text { feedwater and } \\
\text { condensate pumps } \\
P_{p}\end{array}$} & \multirow[t]{4}{*}{4.316} & \multirow[t]{4}{*}{0.75} & $\begin{array}{l}\text { Losses due to feedwater leakage } \\
\text { in regenerative heating system } \\
\mathrm{P}_{\mathrm{pdr}}\end{array}$ & 1.958 & 0.34 \\
\hline & & & $\begin{array}{l}\text { Heat losses in regenerative } \\
\text { feedwater heating system } \mathrm{P}_{\mathrm{qr}}\end{array}$ & 4.075 & 0.72 \\
\hline & & & Unaccounted losses $\Delta \mathrm{P}_{\text {div }}$ & -14.121 & -2.47 \\
\hline & & & TOTAL ENERGY LOSS & 258.551 & 45.24 \\
\hline TOTAL INPUT & $\mathbf{5 7 1 . 4 3 0}$ & 100.00 & TOTAL OUTPUT & 571.430 & 100.00 \\
\hline
\end{tabular}

Table 6. Turbine performance characteristics

\begin{tabular}{|c|c|c|c|}
\hline \multirow[t]{2}{*}{ Nom. } & \multicolumn{3}{|c|}{ Load (condensation) } \\
\hline & $115 \mathrm{MW}$ & $130 \mathrm{MW}$ & $150 \mathrm{MW}$ \\
\hline \multicolumn{4}{|l|}{ High pressure turbine } \\
\hline Theoretical enthalpy drop $\mathrm{H}_{\text {tip }}, \mathrm{kJ} \cdot \mathrm{kg}^{-1}$ & 490.64 & 456.33 & 411.55 \\
\hline Actual enthalpy drop $\mathrm{H}_{\text {iip }}, \mathrm{kJ} \cdot \mathrm{kg}^{-1}$ & 307.22 & 290.37 & 271.52 \\
\hline Isentropic efficiency $\eta_{\text {iip }} \%$ & 62.61 & 63.63 & 65.97 \\
\hline \multicolumn{4}{|l|}{ Reheat turbine } \\
\hline Theoretical enthalpy drop $\mathrm{H}_{\mathrm{tmp}}, \mathrm{kJ} \cdot \mathrm{kg}^{-1}$ & 632.18 & 631.46 & 632.58 \\
\hline Actual enthalpy drop $\mathrm{H}_{\text {imp }}, \mathrm{kJ} \cdot \mathrm{kg}^{-1}$ & 468.47 & 468.77 & 470.82 \\
\hline Isentropic efficiency $\eta_{\text {imp }} \%$ & 74.11 & 74.23 & 74.43 \\
\hline \multicolumn{4}{|l|}{ Low pressure turbine } \\
\hline Theoretical enthalpy drop for $\mathrm{H}_{\mathrm{tip}}, \mathrm{kJ} \cdot \mathrm{kg}^{-1}$ & 615.84 & 588.92 & 543.94 \\
\hline Actual enthalpy drop $\mathrm{H}_{\mathrm{ijp}}, \mathrm{kJ} \cdot \mathrm{kg}^{-1}$ & 505.16 & 483.78 & 465.63 \\
\hline Isentropic efficiency $\eta_{\mathrm{ijp}}, \%$ & 79.87 & 82.15 & 85.60 \\
\hline Theoretical enthalpy drop in turbine $\mathrm{H}_{\mathrm{h}}, \mathrm{kJ} \cdot \mathrm{kg}^{-1}$ & $1.373 \cdot 10^{3}$ & $1.338 \cdot 10^{3}$ & $1.289 \cdot 10^{3}$ \\
\hline Electrical generator efficiency $\eta_{\mathrm{g}}, \%$ & 98.82 & 98.97 & 99.12 \\
\hline Mechanical efficiency $\eta_{\mathrm{m}}, \%$ & 98.31 & 98.54 & 98.73 \\
\hline Turbine isentropic efficiency $\eta_{i}, \%$ & 62.14 & 62.90 & 64.13 \\
\hline Thermal efficiency $\eta_{t}, \%$ & 40.65 & 39.64 & 38.27 \\
\hline Actual efficiency of turbine-generator aggregate $\eta_{e a}, \%$ & 39.52 & 38.66 & 37.45 \\
\hline Specific heat consumption $\mathrm{q}_{\mathrm{bc}}, \mathrm{kJ}_{\mathrm{th}} \cdot \mathrm{kJ}_{\mathrm{e}}{ }^{-1}$ & 2.530 & 2.586 & 2.670 \\
\hline Specific fuel consumption $\mathrm{b}_{\mathrm{bc}}$, (kg e.f.) $\cdot \mathrm{kWh}^{-1}$ & 0.356 & 0.358 & 0.382 \\
\hline Specific energy of main steam $\mathrm{e}_{\mathrm{sp}}, \mathrm{kJ} \cdot \mathrm{kg}^{-1}$ & $1.047 \cdot 10^{3}$ & $1.019 \cdot 10^{3}$ & $0.978 \cdot 10^{3}$ \\
\hline Heat rate, $\mathrm{kJ} \cdot \mathrm{kWh}^{-1}$ & $9.487 \cdot 10^{3}$ & $9.648 \cdot 10^{3}$ & $9.907 \cdot 10^{3}$ \\
\hline Steam rate $\boldsymbol{d}, \mathrm{kg} \cdot \mathrm{kWh}^{-1}$ & 3.436 & 3.532 & 3.679 \\
\hline
\end{tabular}

\section{Conclusions}

Typical efficiency of condensing steam turbines according to literature are in the range of $\eta_{\mathrm{e}}=36$ to $42 \%$ [17], rated efficiency for K 200-130-1 steam turbine [18] is $44.7 \%$, while other data in literature is consistent with data presented above as they show efficiencies of $36 \%$ [19] as well as 37\% HHV (Higher Heating Value) in [20] equivalent to approx. $32 \%$ LHV (Lower Heating Value) [21].

Comparing the values calculated in the process of efficiency assessment, in the range of $\eta_{\text {ea }}=39.71 \%$ for $115 \mathrm{MW}$ load to $37.45 \%$ for $150 \mathrm{MW}$ load, with those presented above can be concluded that the turbine works within the expected range. At the same time, it should be noted that the lower efficiency values are characteristic of low power turbines, as a result the analysed turbine is performing very well. 
Isentropic efficiency for HP turbine is in the range of $\eta_{\text {iip }}=62.61 \%$ to $65.97 \%$ and for the RT turbine in the range of $\eta_{\text {imp }}=74.11 \%$ to $74.43 \%$, lower than expected, but as literature points, the decrease of internal efficiency of turbines in operation occurs often [21], for various reasons. Isentropic efficiency for LP turbine is in the range of $\eta_{\mathrm{ijp}}=79.87 \%$ to $85.60 \%$, as expected.

The heat rate of the turbine is in the range of $9.487 \cdot 10^{3}$ to $9.907 \cdot 10^{3} \mathrm{~kJ} \cdot \mathrm{kWh}^{-1}$ higher than values presented in literature [21].

In the end, can be concluded that the analyzed turbine is working properly, having an efficiency at the higher end of its class.

Higher efficiency means lower coal consumption which will reduce emissions, but higher efficiency also means lower production cost for electricity, thus complying to the Sustainable Development Goals namely affordable and clean energy and responsible consumption and production.

\section{References}

1. https://www.wind-watch.org/news/2017/01/11/renewables-not-cheap-wind-solar-far-higher-costthan-polluting-energy-sources/ (2017)

2. https://energypost.eu/5-charts-show-the-rapid-fall-in-costs-of-renewable-energy/ (2020)

3. NERA, Annual Report on Determining Regulated Prices and Tariffs 2019 (2019)

4. https://ses.jrc.ec.europa.eu/electricity-supply-security-and-resilience

5. https://thehill.com/opinion/energy-environment/503006-we-still-need-coal-to-ensure-powergrid-reliability

6. A. C. Stanci, D. Tataru, A. Stanci, Attenuation of Noise Pollution Produced by Band Conveyors from the Mining Unit of Career Rosia Due to Climatic Conditions, Int J. of Emerging Engineering Research and Technology, vol. 3, 45-50 (2015)

7. https://www.c2es.org/content/renewable-energy/

8. https://ec.europa.eu/eurostat/statistics-explained/pdfscache/9990.pdf

9. https://www.marketsandmarkets.com/Market-Reports/electric-vehicle-market-209371461.html

10. A. Ohji, M. Haraguchi, Steam turbine cycles and cycle design optimization, Advances in Steam Turbines for Modern Power Plants (2017)

11. https://www.energynetworks.com.au/news/energy-insider/the-demise-of-coal/

12. M.S. Bhatt and Rajkumar, N., Performance enhancement in coal fired thermal power plants. Part II: steam turbines. Int. J. Energy Res., 23: 489-515 (1999)

13. Directive NERA nr.2123/2014, Guide to development and analysis of energy balance (2014)

14. I.Gh. Carabogdan, et al., Energy Balances - problems and applications. Tehnica Publishing House, Bucharest (1986).

15. T. Berinde, et al., Elaboration and analysis of energy balance in the industry. Tehnica Publishing House, Bucharest (1976).

16. Technical Instructions and Operation Manual for K-160-130-2PR-2 turbine.

17. E.A., Manushin, Steam turbine, https://www.thermopedia.com/content/1151/

18. Technical Instructions and Operation Manual for K 200-130-1 turbine.

19. I.G.C. Dryden, Efficient Use of Energy, https://doi.org/10.1016/C2013-0-00885-7 (1982)

20. https://www.turbinesinfo.com/steam-turbine-efficiency/

21. A. Sh., Leizerovich, Steam turbines for modern fossil-fuel power plants, Published by The Fairmont Press, Inc. (2008). 